Social Connections and Smallholder Vegetable Farmers' Collaborative Marketing Strategy: The Case of the Small Farmers Association of Quirogpang in Davao City, the Philippines

\author{
M.O. Montiflor, A.K.R. Dela Cerna, R.J.G. Lamban, R.G. Bacus and S.B. Concepcion \\ University of the Philippines Mindanao \\ The Philippines \\ P.J. Batt and R.B. Murray-Prior \\ Curtin University \\ Australia
}

Keywords: collaboration, trust, social capital, cluster

\begin{abstract}
In the Philippines, vegetable farmers generally have only small land holdings. Because of this, plus an apparent lack of financial capital, it is difficult for smallholder farmers to meet the large volume demands imposed by institutional buyers and wholesalers. The small volume and the large variation in quality puts smallholder farmers at a significant disadvantage when it comes to arranging transport and marketing. However, smallholder farmers can engage in collaborative cluster farming in order to meet the demands of the market and to bolster production volume. In the cluster, the farmers carry out production planning and marketing activities collectively. Utilizing the case study method and the 8-step clustering approach formulated by the Catholic Relief Services, this paper will present key success factors and several challenges faced by the Small Farmers Association of Quirogpang (SFAQ) in Marilog, Davao City, Philippines. At the same time, it will identify important institutional supports and strategies that may enhance the success of this and other clusters. The paper highlights key success factors such as the social connections shared by the cluster members and leadership. In this case, these commonalities exist because it is an area-based cluster which includes neighbours and relatives who all practice one religion and speak the same language or dialect.
\end{abstract}

\title{
INTRODUCTION
}

Vegetable farmers in the Philippines usually have very small farms. Because of this and the lack of financial capital, it is difficult for smallholder farmers to meet the quality and quantity demands of institutional market buyers and wholesalers. The low volume produced by a single farmer also puts them at a disadvantage in terms of transport and marketing.

To participate in the emerging institutional market, these small farmers must learn to adjust or unify themselves in order to avoid further marginalization (Boselie, Henson and Weatherspoon, 2003). To compete and participate in modern markets, farmers often form collaborative marketing groups (CMGs). CMGs are groups of farmers who organize themselves to collectively sell their produce (Murray-Prior, 2008). This definition includes cooperatives, growers associations, cluster marketing groups and bargaining cooperatives. 
In Mindanao, there are several vegetable farmer groups that engage in clustering to market their products (Mendoza, 2006; Montiflor, 2007; Montiflor, Batt and MurrayPrior, 2009). These include the Maragusan Vegetable Farmer's Cluster, Northern Mindanao Vegetable Producers Association Inc. and the Vegetable Industry Council of Southern Mindanao Inc. Cluster farming is defined as having individual growers commit to the collective marketing of their products (Uy, 2005; Mendoza, 2006).

In the cluster, the farmers collectively carry out production planning and marketing activities. A study of three clusters in Mindanao by Montiflor (2007) identified issues and challenges faced by farmer groups. These include the sustainability of financial support, the difficulty in sustaining active farmer members, encouraging farmers to cooperate once they are in a cluster, and the need for more farmer leaders.

Montiflor, Batt and Murray-Prior (2009) identified two approaches to cluster farming: an area-based and a commodity-based approach. In the area-based approach, farmers group together based on the proximity of farms, while in the commodity-based approach, farmers plant the same vegetable and combine their output in order to achieve a higher volume. The area-based approach has more social connections, with neighbours and relatives often practicing the same religion and speaking the same language or dialect. Social connections present in the area-based approach are often found in subsistence or semi-subsistence communities (Montiflor et al., 2008).

The case of the Small Farmers Association of Quirogpang (SFAQ) in Marilog is a prime example of an area-based approach. This paper will look into the key success factors and the challenges faced by cluster farmers in Quirogpang and identify what institutional support may be important for the cluster.

\section{Location of the Study}

Sitio Quirogpang is part of Barangay Marilog in Davao City, on the island of Mindanao in the Southern Philippines. The distance from Davao City to Marilog is approximately $51 \mathrm{~km}$. The Barangay has a total land area of 17,833 ha and a population of 14,255 (in August 2007)(National Statistics Office, 2007). In 2007, the population of Sitio Quirogpang was only 225 residents who resided within 33 households.

The only road from the nearest highway to Sitio Quirogpang is a rough dirt track, which often becomes impassable in wet weather. Although tomatoes are a suitable crop, given the high elevation, the roads are muddy and slippery, so it is difficult to transport fruit and other vegetables. Since the farm-to-market road is bad, the cost of transporting the vegetables is $\mathrm{PhP} 1 / \mathrm{kg}$. Aside from vegetables, the main crops planted in the area include cocoa (10 ha) and coffee (7 ha).

\section{History of the Small Farmers Association of Quirogpang (SFAQ)}

The Small Farmers Association of Quirogpang (SFAQ) is the official name of the Quirogpang cluster. The SFAQ was originally an initiative of the People Collaborating for Environmental and Economic Management (PCEEM), Davao Foundation Inc. PCEEM evolved from a five year bilateral project jointly funded by the Philippine government through the Department of Environment and Natural Resources (DENR) and the Canadian government through the Canadian International Development Agency (CIDA).

In April 2006, PCEEM met with church leaders. One of the topics of the meeting was a proposal to include Quirogpang as one of the areas of PCEEM. That same month, 
Sitio Quirogpang church leader, Ms Jesebel Tugap, consulted with Quirogpang residents regarding the proposal.

Most of the community welcomed the PCEEM project. PCEEM sought to investigate ways for the more sustainable management of the Talomo-Lipadas Watershed and the Davao River. The 24 farmers who agreed to support the PCEEM project were also the original members of SFAQ. Some of the assistance provided to the association included a seminar on natural farming and how to manage an association. The venue for these seminars was the parish church.

In March 2007, the Paraiso Farmers' Association (PFA) was formed in another Catholic parish church. SFAQ affiliated with the PFA and their leader, Ms. Tugap, was elected leader of PFA. The reason for the affiliation was the close proximity of Sitio Paraiso to the highway. Unlike Sitio Paraiso, Sitio Quirogpang is some 2-3 km away from the main highway, accessible only by horse, carabao (water buffalo) or by foot. It was easier to conduct activities and provide material support to Sitio Paraiso than to Sitio Quirogpang.

PFA scheduled regular meetings on the first Saturday of every month. However, there were problems such as the long distance of the meeting area from Sitio Quirogpang, misunderstandings with the schedule and no clear agenda during meetings. Eventually, the Quirogpang group stopped coming to the meetings and the PFA membership dwindled. PCEEM staff, who originally assisted SFAQ and saw the group's potential, introduced the Association to the Catholic Relief Services (CRS) in July 2007.

CRS looked into the water supply and identified this as the main problem as the water was unsafe to drink. As a result, CRS (in coordination with PCEEM) constructed a water reservoir. Aside from the reservoir, seminars were conducted on vermiculture and veterinary related activities to take care of livestock.

When PCEEM formally ended in April 2008, CRS continued to assist the group until June 2009, when CRS handed the group over to UP Mindanao.

\section{MATERIALS AND METHODS}

This is a case study which incorporates the process of data collection within the 8step clustering approach formulated by the Catholic Relief Services (CRS, 2007). The first five are preparatory activities (Figure 1). The approach focuses on improving marketing and production activities and involves farmers in a participatory action learning process. Step 1 is site selection, which includes identifying partners and forming working groups. Step 2 involves product supply assessment and selection, in which the key vegetables cultivated in the area are identified and potential focal vegetables selected. Step 3 entails a market survey, where farmers interview prospective buyers and visit institutional buyers such as supermarkets. Steps 4 and 5 are the cluster formation and planning stages. This involves the creation of an agro-enterprise plan for production and marketing. In Step 6, test marketing of the selected vegetable products is conducted, whereby the farmers send their produce to the identified buyer. Assuming it is successful, Step 7 is scaling up. During this stage, the farmers evaluate their test marketing and cluster performance and identify measures to improve the cluster and the members. In Step 8, the cluster may opt to review its enterprise plan or initiate the formation of new clusters. Baseline information was also gathered from 19 cluster members in 2008. Key informant interviews, trips reports and ocular observations were undertaken to enrich the data collection process and analysis. Both qualitative and quantitative analytical processes were used to analyse the data. 


\section{DEVELOPMENT OF THE QUIROGPANG CLUSTER}

Based on the results of the baseline survey, informal interviews and observations, the common production and marketing problems were identified as: (1) very low market price/controlled price; (2) difficult farm access; (3) high cost of transport; (4) lack of access to capital; (5) high cost of fertilizers/pesticides; and (6) limited water supply. Environmental problems included landslides due to unprotected steep farm areas and poor road conditions that worsened during wet weather.

During the database collection/product assessment stage (Step 2), the Quirogpang cluster listed the top 6 vegetables cultivated on the basis of volume. These included eggplants, squash, bitter gourd, Malabar spinach (alugbati), mungbean and string beans. The average monthly household income was only $\mathrm{PhP} 2,500$, well below the poverty line.

As part of an Agro-Enterprise planning workshop conducted in February 2009, farmers were exposed to potential markets. Farmers were able to interview institutional buyers and wet market buyers to obtain information on the market chain, varieties and quality. Farmers went to one large supermarket chain, one local supermarket chain and the Bankerohan wholesale market where they interviewed buyers. In the Bankerohan, the farmers were able to identify potential buyers, quality specifications, volume requirements and alternative modes of payment. Six buyers were identified in the Bankerohan.

In their agro-enterprise plan, the farmers focused on producing three vegetables: squash $(21,545 \mathrm{~kg} /$ year$)$, eggplant $(25,184 \mathrm{~kg} / \mathrm{year})$ and Malabar spinach $(12,700$ $\mathrm{kg} /$ year). The management plan was for the cluster leader to contact the buyer at the Bankerohan. The assistant cluster leader was to manage the packing of the vegetables. The cluster decided, before the first delivery, to give $1 \%$ of the income they received to the cluster.

During test marketing (Step 3), the crops sold included eggplant, sword pepper, Malabar spinach, Baguio beans, taro, banana, okra, bitter gourd, sweet potato and sponge gourd. The agreement was that the buyer would order what kind and volume of vegetables they required every Wednesday. On Thursday, a price range would be sent to the cluster to assist them in deciding whether they would accept the prices offered. On Friday, the vegetables would be collected and paid for. The prices paid for the vegetables ultimately depended on the quality of the vegetables as defined by the buyer. The institutional buyer was to pay the cluster in cash after each transaction.

On the day of delivery, the cluster farmers brought their vegetables to the sorting shed provided by the Catholic Relief Services (CRS). The vegetables brought in were weighed and recorded. There was no quality control as all the vegetables brought in by the farmers were accepted. The cluster promised to pay an average price for all of the vegetables, so the farmers had some idea how much they should receive. The vegetables were then transported via horses to the highway. At the highway, the institutional buyer weighed and classified the vegetables and paid the cluster leader for that produce which they accepted.

After test marketing, the farmers complained that the communication/transaction system that was agreed to during the negotiation had not been followed. The institutional buyer had not been providing prices earlier than Friday, arguing in their defence that they had to check the prices at Crossing S and in the Bankerohan. However, for one cluster in Maragusan, Compostela Valley, supported by UP Mindanao, the institutional buyer was sending information on the volume required and the prices of each vegetable as agreed. 
On the other hand, the buyer complained that the cluster did not provide the agreed volume of vegetables. This was a problem for the buyer since they had travelled specifically to pick up the vegetables promised by the cluster. It was costly for them if they arrived at the pick-up area and did not get the volume and variety of products they had ordered.

There was also some disagreement about the quality of the products delivered. The buyer stipulated what they called Class A quality vegetables. However, the characteristics of Class A quality vegetables were not accurately described.

Another issue was the calibration of the scales, with the total weight measured by the cluster's scale being slightly higher than for the buyer's scale. As the buyer's scale was being used to determine the total volume and value, this presented a problem because the cluster's record of weight was used to pay the farmers. To ensure that cluster members made subsequent deliveries, the cluster leader paid the full amount to the farmers based on the cluster weighing scale. As a result, the cluster had to absorb the loss. Furthermore, those vegetables which did not pass the standards of the institutional buyer were sold in the Bankerohan for a lower price.

Although the farmers were getting a better price from the institutional buyer compared to selling at Crossing $\mathrm{S}$, they were still unhappy. The farmers received $\mathrm{PhP}$ $14 / \mathrm{kg}$ for eggplant while the price in Crossing $\mathrm{S}$ was only $\mathrm{PhP} 10 / \mathrm{kg}$. Aside from eggplant, the farmers also received a better price for Malabar spinach and sword pepper. The price of sword pepper, for example, was $50 \%$ higher than at Crossing $\mathrm{S}$ (Table 1). Farmers appeared to be hoping that they would get the prices paid by buyers in the Bankerohan, but they failed to allow for the cost of transport to the Bankerohan. In addition, the agro-enterprise plan had raised their expectations by including unrealistic projections of prices. Farmers failed to consider the risks associated with having to take whatever price was offered once their vegetables reached the Bankerohan market. It also appeared that they were able to sell a wider range of vegetables than at Crossing $S$.

At present, with the facilitation of the UP Mindanao project team, the cluster and the institutional buyers are still transacting and looking for some means to address the issues. Limited market options have forced the farmers to continue to transact with the institutional buyer and to sell to wholesalers in the Bankerohan (Figure 2).

The farmers usually have local buyers from Crossing S. A local buyer is one who supplies a mall in Tagum City or Davao City. There are also buyers/traders who regularly come to Crossing $\mathrm{S}$ to buy vegetables brought in by the farmers. Some farmers from Quirogpang opt to take their produce to the Bankerohan public market themselves and to sell to that buyer who offers the best price.

From February 2009 to January 2010, an estimated 5,866 kg of assorted vegetables were produced by the cluster (Table 2). The total value amounted to $\mathrm{PhP}$ 59,992. From August 2009 to January 2010, the cluster sold vegetables to the institutional market ten times and to the Bankerohan public market. The largest volume was delivered to the Bankerohan (71\%). However, in terms of value, sales to the Bankerohan provided only $58 \%$ of the total amount received by the cluster.

There is also a local buyer whom the cluster previously sold to when they were still transacting as individual farmers. This local buyer pays a higher price in comparison to the prevailing price at Crossing S. This local buyer was not concerned about quality and purchased almost all of the vegetables brought in by cluster members. 


\section{CHANGES AND CHALLENGES ARISING FROM CLUSTER ACTIVITIES}

The farmers continue to sell vegetables to the institutional buyer and to the public market. The supermarket is satisfied with the consistency of supply and the quality so they continue to order from the farmers. The farmers are also aware that the institutional market cannot accept all the produce that they grow and so they must sell some to local buyers and wholesalers in the wet market. However, this has not discouraged them from supporting their collaborative marketing group. This option has created an alternative market for the farmers' produce and improved their understanding of how market prices are derived. Each farmer within the cluster is entitled to voice his or her opinion during meetings and gatherings which enhances the richness of experiences and ideas.

There are several issues and challenges faced by the Quirogpang cluster. These include: (i) the need for additional volume and a greater product assortment; (ii) problems in negotiating with the institutional buyer over quality standards; (iii) problems with calibration of scales; (iv) the inability of farmers to calculate the farm-gate price; and (v) inaccessible farm-to-market roads.

Some of the possible interventions are to have a third party calibrate the weighing scales used by both the buyer and the cluster. This will address complaints from both parties as to whose scale is most accurate. There should also be some dialogue to discuss the quality specifications of the buyer. One way to start the discussion may be to use the quality specifications as utilised by another institutional buyer as a guide. If both the buyer and the farmers agree on the quality standards, haggling over quality during delivery will be curtailed and both will benefit from the transaction. The buyer will get the desired quality while the farmers will receive a fair price.

At present, the vegetables chosen by the farmers are the tropical varieties such as squash, eggplant, Malabar spinach and bitter gourd as the farmers are more familiar with the production protocols for these vegetables. Although the City Agriculturist's Office has provided temperate vegetable seeds such as carrots and lettuce, the farmers have yet to plant these vegetables. The main reason is that these crops are new to them and they have little to no experience. Furthermore, Quirogpang farmers cannot afford to conduct trials because most of them are self-financed. They have limited money to invest in vegetable production. Therefore, they need to have access to capital or to be provided with some loan assistance from support organisations.

\section{KEY LESSONS AND SUCCESS FACTORS}

Key success factors for the cluster are having: (1) alternative markets; (2) strong leadership; (3) open communication; (4) trust; (5) social connections; and (6) strong institutional support.

Institutional support has been crucial to the success of this cluster, just as it was for three other clusters in Northern and Southern Mindanao (Montiflor, 2007). This support includes on-going training, workshops and field visits for vegetable production, post-harvest training and marketing. For SFAQ, aside from the market linkages, they also received support from other government and non-government agencies. CRS-PCEEM provided them with a water reservoir and CRS initially provided field officer support and also provided the sorting shed. UP Mindanao provided support from a field officer plus material support for a sorting shed which also doubles as a waiting shed at Crossing S. Other support includes seeds, fertilizers, crates and seed trays from the Department of Agriculture through the Davao City Agriculturist's Office (CAO). 
Cluster cohesion is enhanced by the social connections between its members. Most of the members belong to the same family, the same church group and speak the same language. The cluster leader and officers are in constant contact with the members and members give feedback for any improvements or problems to be addressed. Leaders were chosen by the farmers themselves and not by outsiders. There is trust among the members since they handed over the responsibility of collating, selling and negotiating the sale of the vegetables to one person.

In the SFAQ, it was noted that 14 out of the 19 members belong to three families. In one family, there were ten cluster members. This included the parents, sons, daughters, in-laws and cousins. The other two families were composed of brothers. Most of the members also speak Cebuano and the cluster members belong to the Gagmay'ng Kristohanong Katilingban (GKK) or Small Christian Communities, a Catholic Church. Lin (1999) said that those networks that are closer and have more intimate and reciprocal relations, such as family and relatives, may encourage others to join and protect existing resources.

The cluster has a strong leader who the members trust. The cluster leader is also a GKK and Purok Leader. She is the major motivator of the cluster activities and the members place a high degree of trust in her. She represents the cluster at numerous meetings and workshops and negotiates directly with the buyers.

Trust is one of the most important factors that strengthen collaboration (Batt and Purchase, 2004). Personal and process-based trust is very important in a collaborative relationship (Kotilla and Ronni, 2008). However, building collaborative relationships is often difficult (Dunne 2008). Time, resources and management skill have been invested over some time to develop this trust.

As Sitio Quirogpang is inaccessible by most motor vehicles, the roads are bad, the distance from the highway is long and tedious, the population is small, and the area is quite isolated, people living there tend to help each other.

\section{CONCLUSION}

In the case of SFAQ, there are several key success factors and challenges for the cluster. Positive factors include:

- $\quad$ high levels of social capital and effective leadership

- $\quad$ strong institutional support

- a committed institutional buyer

- $\quad$ strong social connections

- a high degree of trust towards the cluster leader

Issues to be addressed include:

- $\quad$ the need to standardise quality standards

- $\quad$ the need to standardise weighing scales

- an improved understanding of market prices and the calculation of farm-gate prices

- $\quad$ access to capital

- landslides due to unprotected steep farm areas and poor road conditions that worsen during wet weather 


\section{Acknowledgements}

Australian Centre for International Agricultural Research (ACIAR), Mr. Ludovico Ramirez, Jr., Ms. Betty Fuenconcillo, Jessan Catre and the Catholic Relief Services.

\section{Literature Cited}

Batt, P.J. and Purchase, S. 2004. Managing collaboration within networks and relationships. Industrial Marketing Management 33, 169-174.

Boselie, D., Henson, S. and Weatherspoon, D. 2003. Supermarket procurement practices in developing countries: redefining the roles of public and private sectors. American Journal of Agricultural Economics, 85(5): 1155-1161.

Catholic Relief Services. 2007. The Clustering Approach to agroenterprise development for small farmers: The CRS-Philippines Experience - A Guidebook for Facilitators. Catholic Relief Services - USCCB Philippine Program.

Dunne, A.J. 2008. The impact of an organization's collaborative capacity on its ability to engage its supply chain partners. British Food Journal, 110(4/5): 361 - 375.

Kottila M.R. and Ronni, P. 2008. Collaboration and trust in two organic food chains. British Food Journal, 110(4/5): 376-394.

Lin, N. 1999. Building a Network Theory of Social Capital. Connections 22(1): 28-51.

Mendoza, L. 2006. The experiences of CRS in Clustering. Third Mindanao Vegetable Congress. Cagayan de Oro City.

Montiflor, M.O. 2007. Cluster farming as a vegetable marketing strategy: The case of smallholder farmers in Southern and Northern Mindanao. Acta Hort. 794: 229-238.

Montiflor, M.O., Batt, P.J. and Murray-Prior, R. 2008. Cluster farms in Mindanao, Philippines: Do vegetable farmers get what they expect? Banwa 8(2): 10-21.

Montiflor, M.O., Batt, P.J. and Murray-Prior, R. 2009. Socio-economic impact of cluster farming for smallholder farmers in Southern Philippines. Acta Hort 809: 193-200.

Murray-Prior, R. (2008). Are farmers in transitional economies likely to benefit from forming collaborative marketing groups? Banwa, 8(2): 10-21.

National Statistics Office 2007 Census of Population (Publication. Retrieved January 21, 2010, from National Statistics Office: http://www.census.gov.ph/data/sectordata/2007/region\%2011.pdf)

Uy, J.C. 2005. Cluster Farming: The NorminVeggies Experience. Second Mindanao Vegetable Congress, Davao City, Philippines 17-19 August. 
Table 1: Test marketing volume and value of institutional market in comparison with local buyers

\begin{tabular}{lrrrr}
\hline Vegetable & $\begin{array}{c}\text { Institutional } \\
\text { buyer quantity } \\
(\mathrm{kg})\end{array}$ & $\begin{array}{c}\text { Institutional } \\
\text { buyer price } \\
(\mathrm{PhP})\end{array}$ & $\begin{array}{c}\text { Value of } \\
\text { institutional sales } \\
(\mathrm{PhP})\end{array}$ & $\begin{array}{c}\text { Crossing S } \\
\text { price } \\
(\mathrm{PhP})\end{array}$ \\
\hline Eggplant & 48 & 14.00 & 672 & 10.00 \\
Sweet potato & 48 & 7.50 & 360 & \\
Banana & 36 & 4.00 & 144 & 4.00 \\
Baguio beans & 23 & 20.00 & 460 & 20.00 \\
Malabar spinach & 22 & 8.00 & 173 & 4.00 \\
Taro & 15 & 7.50 & 113 & \\
Sword pepper & 10 & 23.00 & 230 & 15.00 \\
Sponge gourd & 9 & 5.00 & 45 & \\
Okra & 6 & 10.00 & 60 & \\
Bitter gourd & 2 & 20.00 & 40 & \\
\hline Total & 219 & & & \\
\hline
\end{tabular}

Table 2: Volume, value and buyers of vegetables produced by SFAQ (August 09 - January 10)

\begin{tabular}{lrrrrr}
\hline Buyer & Times & \multicolumn{2}{c}{ Volume } & \multicolumn{2}{c}{ Value } \\
& bought & \multicolumn{1}{c}{$\mathrm{Kg}$} & \multicolumn{1}{c}{$\%$} & \multicolumn{1}{c}{$\mathrm{PhP}$} & \multicolumn{1}{c}{$\%$} \\
\hline Institutional buyer & 10 & 1,601 & $27 \%$ & 20,643 & $34 \%$ \\
Bankerohan market & 10 & 4,149 & $71 \%$ & 34,865 & $58 \%$ \\
Rizal Park Davao City & 1 & No data & & 2,144 & $4 \%$ \\
Local buyer & 1 & 117 & $2 \%$ & 2,340 & $4 \%$ \\
\hline Total & & 5,866 & & 59,992 & \\
\hline
\end{tabular}

Figure 1: CRS 8-step approach to clustering approach Source: CRS 2007

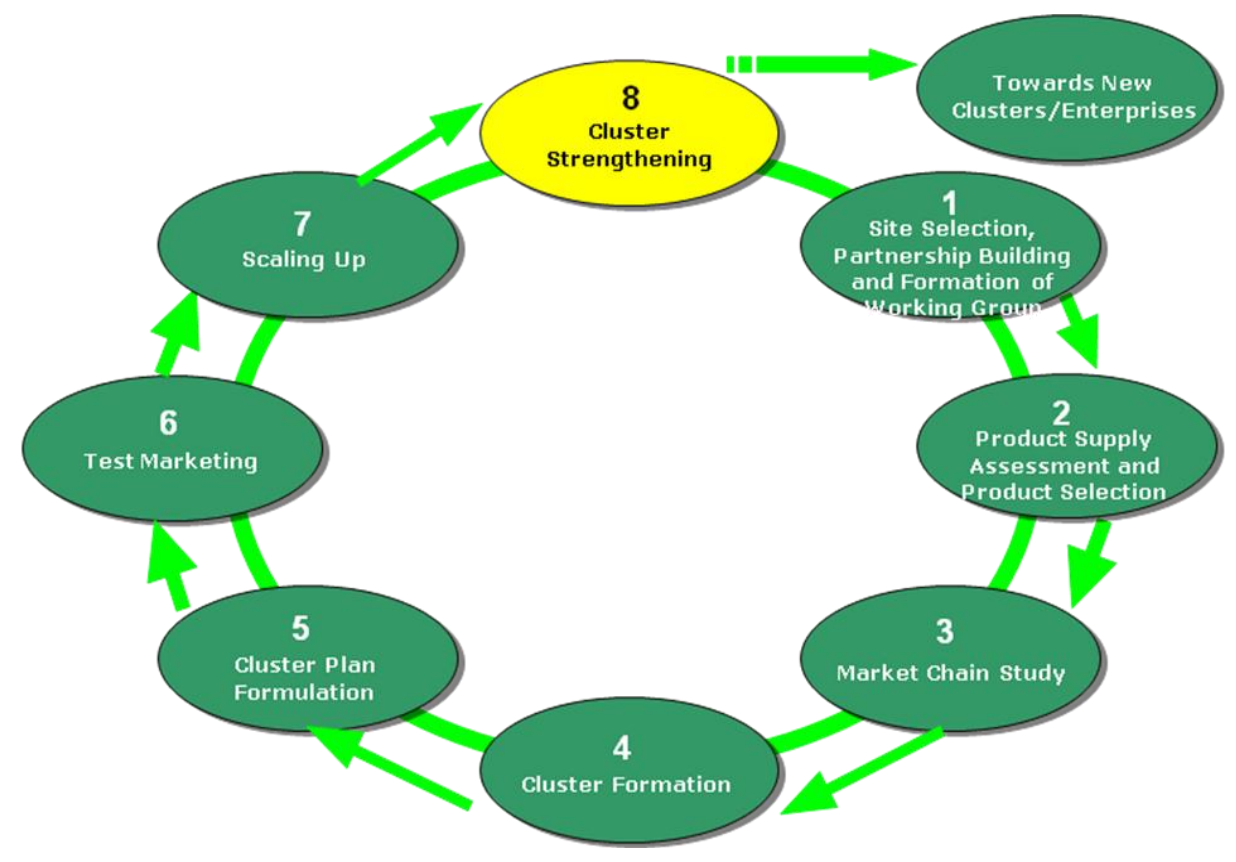


Figure 2: Vegetable supply chains of Sitio Quirogpang cluster

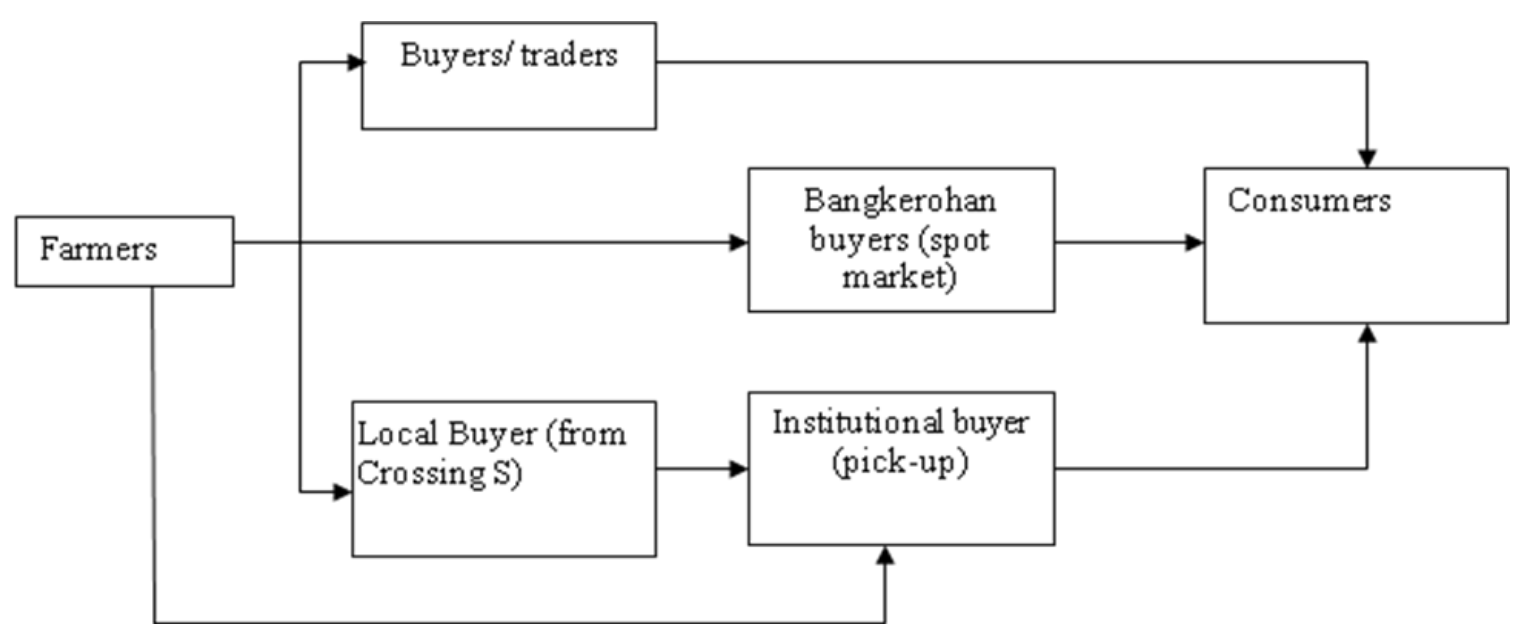

